\title{
Hemoglobin A1c Measurement Using Point of Care Testing
}

\author{
Hasta Başı Test Cihazları Kullanarak Hemoglobin A1c Ölçümü
}

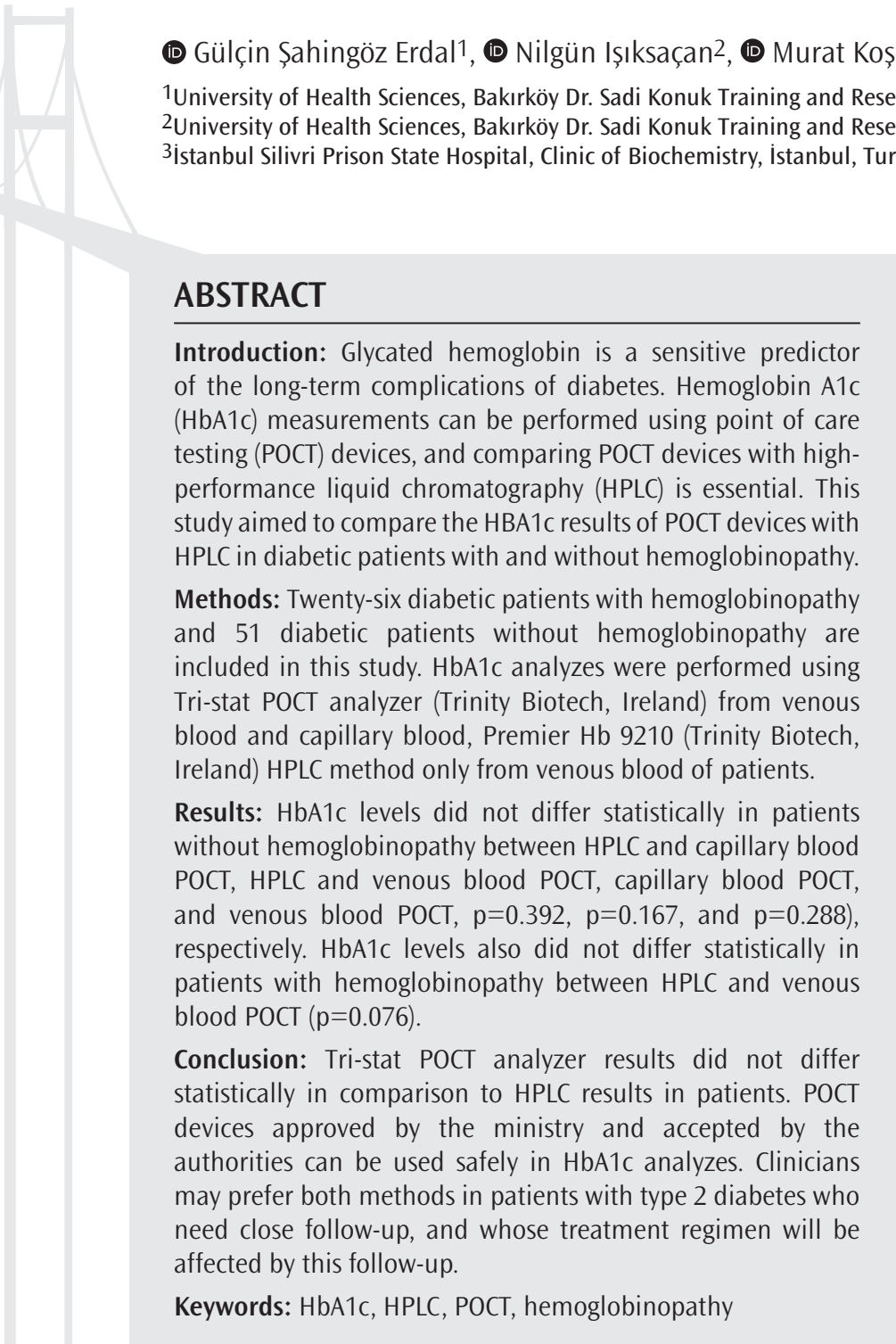

$\ddot{0 Z Z}$

Amaç: Hemoglobin A1c (HbA1c) diyabetin uzun dönem komplikasyonlarını hassas olarak belirlemektedir. HbA1c ölçümleri hasta başı test cihazları (HBTC) ile yapılabilmekte olup, bu HBTC'lerin yüksek performanslı sıvı kromatografi (HPLC) ile kıyaslanması önem arzetmektedir. Bu çalışmada hemoglobinopatisi olan ve olmayan hastaların $\mathrm{HbA1C}$ sonuçlarının HBTC HbA1c cihazı (Tri-stat Analyzer, Trinity Biotech) ve HPLC ( $\mathrm{Hb}$ Premiere) ile karșılaștırılması amaçlanmıștır.

Yöntemler: Hemoglobinopatili 26 diyabetik, hemoglobinopatisiz 51 diyabetik hasta çalışmaya alındı. Hastaların HbA1C analizleri Tri-stat HBTC kullanılarak (Trinity Biotech, Ireland) venöz ve kapiller kandan, Premier Hb 9210 (Trinity Biotech, Ireland) HPLC kullanılarak sadece venöz kandan çalışılmıștır.

Bulgular: Hemoglobinopatisi olmayan hastaların $\mathrm{HbA} 1 \mathrm{C}$ düzeyleri karșılaştırıldığında HPLC - kapiller kan HBTC arasında $(p=0,392)$, HPLC - venöz kan HBTC arasında $(p=0,167)$ ve venöz kan HBTC - kapiller kan HBTC arasında $(p=0,288)$ istatistiksel olarak anlamlı bir fark saptanmamıștır. Hemoglobinopatisi olan hastaların HbA1c düzeyleri karşılaștırıldığında HPLC venöz kan HBTC arasında da $(p=0,076)$ istatistiksel olarak anlamlı bir fark saptanmamıștır.

Sonuç: Hastalarda, Tri-stat HBTC'yi HbA1c sonuçları HPLC ile karșılaștırıldığında istatistiksel olarak farklı değildi. Bakanlıkça onaylı ve otoriteler tarafından kabul gören HBTC'yi HbA1c analizlerinde güvenle kullanılabilir. Klinisyenler, yakın takibe ihtiyaç duyan ve tedavi rejimi bu takipten etkilenecek tip 2 diyabetli hastalarda her iki yöntemi de tercih edebilirler.

Anahtar Kelimeler: HbA1c, HPLC, HBTC, hemoglobinopati
Address for Correspondence/Yazıșma Adresi: Gülçin Şahingöz Erdal MD, University of Health Sciences, Bakırköy Dr. Sadi Konuk Training and Research Hospital, Clinic of Internal Medicine, İstanbul, Turkey

Phone: +90 5316427516 E-mail: gulcinctf@hotmail.com ORCID ID: orcid.org/0000-0001-5815-5847

Cite this article as/Atıf: Şahingöz Erdal G, Ișıksaçan N, Koșer M, Kocamaz N. Hemoglobin A1c Measurement Using Point of Care Testing. İstanbul Med J 2020; 21(1): 37-41.
Received/Geliș Tarihi: 16.08 .2019 Accepted/Kabul Tarihi: 29.10.2019

(C) Copyright 2020 by the Istanbul Training and Research Hospital/istanbul Medical Journal published by Galenos Publishing House.

(C) Telif Hakkı 2020 İstanbul Ĕğitim ve Araștırma Hastanesi/Istanbul Tıp Dergisi, Galenos Yayınevi tarafından basılmıștır. 


\section{Introduction}

Regular monitoring of glycated hemoglobin subfraction A1c (HbA1c) in people with diabetes and treatment with glucose-lowering medications to improve glycemic control can reduce the risk of developing complications (1). In the past, the recommended method for the diagnosis of diabetes was through the repeated measurement of fasting plasma glucose or an oral glucose tolerance test (2). More recently, the measurement of the glycated fraction ( $\mathrm{HbA1c}$ ) of $\mathrm{HbA} 1 \mathrm{c}$ has been recommended to diagnose diabetes (3), in addition to monitoring glycemic control. Glycated hemoglobin is a sensitive predictor of the long-term complications of diabetes. High HbA1c levels are strongly linked to increased risk of cardiovascular disease, nephropathy, and retinopathy $(4,5)$ and predict most of the excess mortality risk in men with diabetes (6).

The traditional method of testing for glycemic control in primary care involves sending blood samples for laboratory testing and waiting several days for results. In parallel with the developments of nanotechnology in biomedical applications, point of care testing (POCT) of HbA1c is available using a non-invasive, quick and easy analysis. POCT devices are especially useful in emergency departments, in general practitioner's offices or in distant locations to reference laboratories. POCT can also improve the life quality in chronic patients $(7,8)$.

This study aimed to compare HBA1c results of the POCT HbA1c device (Tri-stat Analyzer, Trinity Biotech) with high-performance liquid chromatography (HPLC) (Hb Premiere) in diabetic patients with and without hemoglobinopathy.

\section{Methods}

Twenty-six diabetic patients with- and 51 patients without hemoglobinopathy who admit to University of Health Sciences, Bakırköy Dr. Sadi Konuk Training and Research Hospital, outpatient clinic, were enrolled. The American Diabetes Association (ADA) criteria were used to diagnose diabetes (9).

All patients signed an informed consent form before being enrolled, and the study protocol was approved by the University of Health Sciences, Bakırköy Dr. Sadi Konuk Training and Research Hospital Local Ethical Committee (decision no: 2014/231). There was no statistically significant difference between age and sex distributions of the two groups.

HbA1c analyzes were performed using Tri-stat POCT analyzer (Trinity Biotech, Ireland) from venous blood and capillary blood, Premier $\mathrm{Hb}$ 9210 (Trinity Biotech, Ireland) HPLC method only from venous blood of patients.

\section{Statistical Analysis}

Mean, standard deviation, median, minimum, and maximum values were given for continuous variables. The normal distribution of continuous variables was tested by the Kolmogorov-Smirnov test. For dependent variables showing normal distribution, the Dependent t-test was used in the comparison of two groups. Bland Altman analysis was used for comparisons between methods. The Intraclass Correlation Coefficient (ICC) was calculated for the degree of correlation and agreement between measurements of the methods. P values lower than 0.05 , with a $95 \%$ confidence interval, were considered as statistically significant.

\section{Results}

The median age of the 51 patients without hemoglobinopathy (32 women and 19 men, the ages ranged between 20 and 78 years) was $53.27 \pm 11.80$ years of age. Only one person in this group had chronic renal failure, who did not receive hemodialysis.

The mean HbA1c level of this group analyzed by the HPLC method, by POCT from venous blood and by POCT capillary blood was $8.45 \pm 2.30$, $8.54 \pm 2.18$ and $8.50 \pm 2.16$, respectively.

No statistically significant difference was observed between HPLC HbA1C and capillary blood POCT HbA1C measurements ( $p=0.392)$.

No statistically significant difference was also observed between the HPLC - HbA1C and venous blood POCT HbA1C $(p=0.167)$. POCT - HbA1C measurements from capillary blood and concurrent venous blood did not differ statistically ( $p=0.288)$ (Table 1$)$.

ICC of HPLC - HbA1C and POCT - HbA1C capillary measurements, HPLC HbA1C - POCT HbA1C venous blood and POCT - HbA1C capillary - POCT - HbA1C venous blood is 0.988 (0.980-0.993), 0.989 (0.980-0.994) and

Table 1. Comparison of the capillary and venous blood results of point of care testing analysis with high-performance liquid chromatography method

\begin{tabular}{|l|l|l|}
\hline & Mean \pm SD & p \\
\hline HPLC HbA1C & $8.45 \pm 2.38$ & 0.392 \\
\hline POCT HbA1C capillary & $8.5 \pm 2.16$ & \\
\hline HPLC HbA1C & $8.45 \pm 2.38$ & 0.167 \\
\hline POCT HbA1C venous (EDTA) & $8.54 \pm 2.18$ & \\
\hline POCT HbA1C capillary & $8.5 \pm 2.16$ & 0.288 \\
\hline POCT HbA1C venous (EDTA) & $8.54 \pm 2.18$ & \\
\hline
\end{tabular}

SD: standard deviation, POCT: point of care testing, HPLC: high-performance liquid chromatography, HbA1C: hemoglobin A1c, EDTA: ethylenediaminetetraacetic acid

Table 2. Intraclass correlation of the capillary and venous blood results of the point of care testing analysis and high-performance liquid chromatography

\begin{tabular}{|c|c|c|c|}
\hline & \multirow{2}{*}{ Intraclass correlation coefficient } & \multicolumn{2}{|c|}{ 95\% Confidence interval } \\
\hline & & Lower bound & Upper bound \\
\hline HbA1C / P0CT HbA1C capillary & 0.988 & 0.980 & 0.993 \\
\hline HbA1C / P0CT HbA1C venous (EDTA) & 0.989 & 0.980 & 0.994 \\
\hline POCT HbA1C capillary / POCT HbA1C venous (EDTA) & 0.997 & 0.995 & 0.998 \\
\hline
\end{tabular}


0.997 (0.995-0.998), respectively. All of them indicate strong reliability (Table 2) (Figures 1, 2, 3).

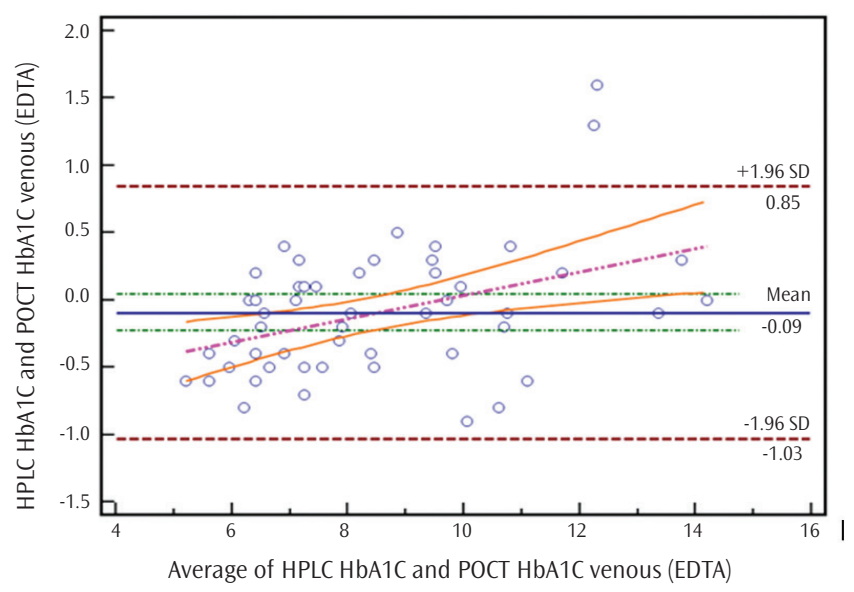

Figure 1. Bland Altman analysis of HPLC HbA1C - POCT HbA1C venous blood measurement

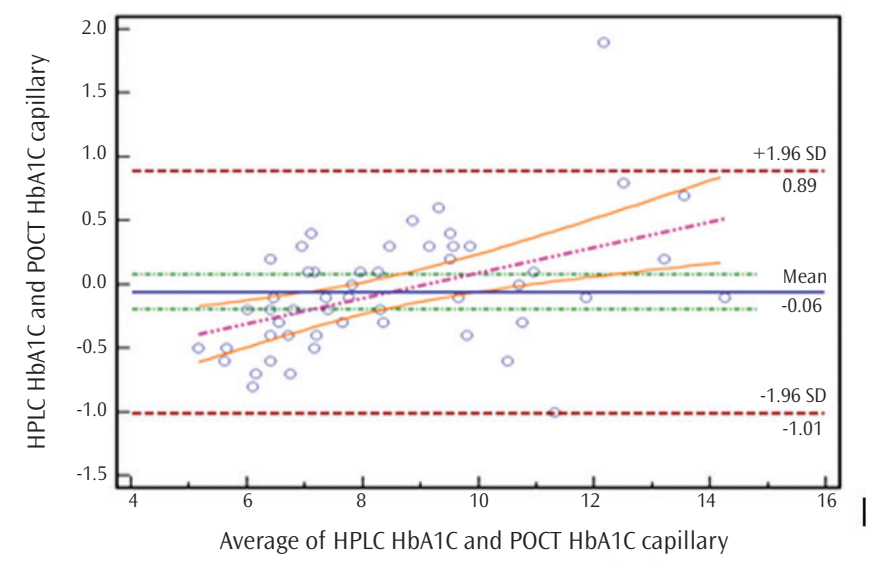

Figure 2. Bland Altman plot of HPLC- HbA1C and POCT- HbA1C capillary blood measurement

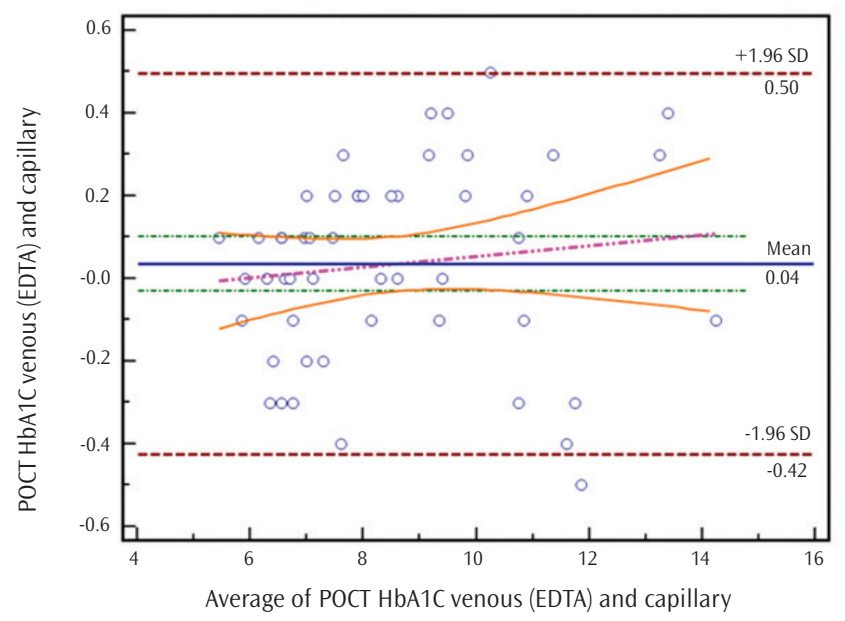

Figure 3. Bland Altman plot of POCT HbA1C capillary - POCT HbA1C venous blood measurement
Mean $\mathrm{HbA} 1 \mathrm{C}$ level of 26 patients with hemoglobinopathy and type 2 diabetes analyzed by the HPLC method and by POCT was $6.78 \pm 1.45$ and $6.45 \pm 1.38$, respectively. No statistically significant difference was observed $(p=0.076)$ (Table 3).

ICC of HPLC - HbA1C and POCT - HbA1C is 0.994 (0.990-0.997), which indicates strong reliability (Table 4).

\section{Discussion}

The ADA guidelines (2010) recommend the use of glycosylated hemoglobin (HbA1c) levels for screening and diagnosis of diabetes (10). Thus, accurate measurement of HbA1c levels is essential for the optimal management of diabetes (11-13).

In recent years, international standardization organizations such as the National Glycohemoglobin Standardization Program and the International Federation of Clinical Chemistry have helped to improve the quality of $\mathrm{HbA1c}$ determination (14).

$\mathrm{HbA1C}$ measurement is an essential tool in the management of patients with diabetes mellitus. In this context, the possibility of having rapid and accurate methods for HbA1c evaluation is significant.

Several techniques are used for laboratory determination of serum $\mathrm{HbA1c}$ levels. The most frequently used form is affinity chromatography, both manual chromatography, and affinity HPLC. As affinity chromatography in principle measures not only the specific glycation on the $\beta$-N-terminal, but also on the $\alpha$ - $N$-terminal and $\varepsilon$-residues of the total hemoglobin molecule, the end-result is total glycated hemoglobin or glycohemoglobin (15).

There are some disadvantages in clinical practice, although the reliability, widespread use, and standardization of laboratory methods are possible.

Physicians in ambulatory settings routinely send blood samples to laboratories for $\mathrm{HbA} 1 \mathrm{c}$ testing and wait several days for the HbA1c test results. Thus, patient counseling and treatment adjustments based on $\mathrm{HbA1C}$ levels are delayed, and at times follow-up can be lost entirely.

Table 3. Hemoglobin A1c levels of patients with hemoglobinopathy (high-performance liquid chromatography and point of care testing)

\begin{tabular}{|l|l|l|l|}
\hline & Mean & SD & p \\
\hline HbA1C (HPLC) & 6.78 & 1.45 & 0.076 \\
\hline HbA1C (POCT) & 6.45 & 1.38 & \\
\hline
\end{tabular}

SD: standard deviation, HbA1C: hemoglobin A1c, POCT: point of care testing, HPLC: high-performance liquid chromatography

Table 4. Intraclass Correlation Coefficient of high-performance liquid chromatography and point of care testing of patients with hemoglobinopathy

\begin{tabular}{|l|l|l|l|} 
HPLC / POCT & $\begin{array}{l}\text { Intraclass } \\
\text { correlation } \\
\text { coefficient }\end{array}$ & \multicolumn{2}{|l}{$\mathbf{9 5 \% \text { Confidence interval }}$} \\
\hline HbA1C & 0.994 & Lower bound & Upper bound \\
\hline P & 0.990 & 0.997
\end{tabular}

POCT: point of care testing, HPLC: high-performance liquid chromatography 
POCT devices can provide excellent convenience for patients receiving home care services, or in places where healthcare facilities are not easy to access. These devices are small, portable, and not expensive. They are easy to use and do not require extensive training.

Several HbA1c POCT devices are currently available for use in clinical practice, including Bayer's A1CNow $+{ }^{\circledR}$ Multi-test A1C System (A1CNow + ), the inzit (II) Analyzer (in2it; Bio-Rad Laboratories), the DCA Vantage Analyzer (DCA Vantage; Siemens Healthcare Diagnostics, Inc.), Tri-stat POCT analyzer (Trinity Biotech, Ireland) and the Afinion AS100 Analyzer System (Afinion; Axis-Shield Point-of-Care).

Although new devices are developed every day, the standardization problem and the lack of adequate studies negatively affect the usage of these devices widely.

Our study evaluates a fast and easy way to perform Tri-stat POCT analyzer measurements of glycated hemoglobin $\mathrm{HbA1c}$ in comparison with an immunoassay on an automated biochemistry analyzer, Premier Hb 9210 (Trinity Biotech, Ireland), the methods routinely used in our clinical laboratories for the measurement of $\mathrm{HbA} 1 \mathrm{c}$

In previous studies, POCT analyses were consistent with the HPLC method, but the POCT -HbA1c level was lower than HPLC. In their study, Schwartz et al. (16) compared the performance of the BIO-RAD Micromat II POCT device with a laboratory-based HPLC method (Primus Model 386) for measurement of HbA1c. For each of the laboratory methods, the correlation coefficient was lower than the 0.96 reported by the manufacturer. HbA1c results were also consistently lower than those obtained from laboratory analysis.

Grant et al. (17) compared HPLC and Quo-Test analyzer and obtained similar results. In another study, Arsie et al. (18) reported similar results after comparing HPLC and DCA 2000 POCT analyzer.

In our study, although the results of HPLC and Tri-stat were strongly correlated, however, POCT HbA1c levels were not lower than the results of HPLC, as in the studies mentioned above, even slightly higher. These results did not change in capillary and venous blood samples. These almost identical results may encourage clinicians to rely on this method, which is less invasive for the patient and allows bedside analysis.

Although Tri-stat POCT analyzer results did not differ statistically in comparison to HPLC results in patients with hemoglobinopathy in our study, they were lower than HPLC. This condition may be associated with the shortened lifespan of erythrocytes. Haliassos et al. (19) obtained similar results like ours. In this study, HbA1c levels of patients with hemoglobinopathy were compared using DCA 2000 of Bayer Diagnostics (Tarrytown, NY, USA) and HPLC.

As a result, Tri-stat POCT analyzer results did not differ statistically in comparison to HPLC results in patients. POCT devices approved by the ministry and accepted by the authorities can be used safely in HbA1c analyzes.

\section{Conclusion}

Clinicians may prefer both methods in patients with type 2 diabetes who need close follow-up, and whose treatment regimen will be affected by this follow-up. The POCT analyzers should be evaluated for diagnostic purposes by professional organizations developing clinical guidelines.

Ethics Committee Approval: The study protocol was approved by the University of Health Sciences, Bakırköy Dr. Sadi Konuk Training and Research Hospital Local Ethical Committee (decision no: 2014/231).

Informed Consent: All patients signed an informed consent form before being enrolled.

Peer-review: Externally peer-reviewed.

Author Contributions: Surgical and Medical Practices - G.Ş.E., M.K., N.K.; Concept - N.I.; Design - M.K., N.I.; Data Collection and/or Processing - N.I.; Analysis and/or Interpretation - G.S.E., N.I.; Literature Search G.S.E.; Writing Manuscript - G.Ş.E.

Conflict of Interest: No conflict of interest was declared by the authors.

Financial Disclosure: The authors declared that this study received no financial support.

\section{References}

1. Stratton IM, Adler AI, Neil HA, Matthews DR, Manley SE, Cull CA, et al. Association of glycaemia with macrovascular and microvascular complications of type 2 diabetes (UKPDS 35): prospective observational study. BMJ 2000; 321: 405-12.

2. Alberti KG, Zimmet PZ. Definition, diagnosis and classification of diabetes mellitus and its complications. Part 1: diagnosis and classification of diabetes mellitus provisional report of a WHO consultation. Diabet Med 1998; 15: 53953.

3. Ejilemele A, Unabia J, Ju H, Petersen JR. A1c Gear: Laboratory quality HbA1c measurement at the point of care. Clin Chim Acta 2015; 445: 139-42.

4. Effect of intensive diabetes treatment on the development and progression of long-term complications in adolescents with insulin-dependent diabetes mellitus: Diabetes Control and Complications Trial. Diabetes Control and Complications Trial Research Group. J Pediatr 1994; 125: 177-88.

5. Intensive blood-glucose control with sulphonylureas or insulin compared with conventional treatment and risk of complications in patients with type 2 diabetes (UKPDS 33). UK Prospective Diabetes Study (UKPDS) Group. Lancet 1998; 352: 837-53

6. Khaw KT, Wareham N, Luben R, Bingham S, Oakes S, Welch A, et al. Glycated haemoglobin, diabetes, and mortality in men in Norfolk cohort of european prospective investigation of cancer and nutrition (EPIC-Norfolk). BM] 2001; 322: $15-8$.

7. Jermendy G, Nádas ], Farkas K. [Rapid hemoglobin A1c determination (a new possibility in diabetes care)]. Orv Hetil 1999; 140: 1251-4.

8. Gebrekidan A, Gill G, Wile D, Tesfaye S. An accurate and portable system for glycated haemoglobin measurement in the tropics. Trop Doct 2004; 34: 94-5.

9. American Diabetes Association. 2. Classification and Diagnosis of Diabetes: Standards of Medical Care in Diabetes-2018. Diabetes Care 2018; 41: 13-27.

10. American Diabetes Association. Standards of medical care in diabetes-2010 Diabetes Care. 2010 Jan;33 Suppl 1:S11-61. doi: 10.2337/dc10-S011. Erratum in: Diabetes Care 2010; 33: 692

11. Finke A, Kobold U, Hoelzel W, Weykamp C, Miedema K, Jeppsson JO. Preparation of a candidate primary reference material for the international standardisation of HbA1c determinations. Clin Chem Lab Med 1998; 36: 299308.

12. Kobold U, Jeppsson JO, Dülffer T, Finke A, Hoelzel W, Miedema K. Candidate reference methods for hemoglobin A1c based on peptide mapping. Clin Chem 1997; 43: 1944-51. 
13. Sacks DB, Arnold M, Bakris GL, Bruns DE, Horvath AR, Kirkman MS, et al. National Academy of Clinical Biochemistry. Position statement executive summary: Guidelines and recommendations for laboratory analysis in the diagnosis and management of diabetes mellitus. Diabetes Care 2011; 34: 1419-23.

14. Heinemann L, Freckmann G. Quality of HbA1c Measurement in the Practice: The German Perspective. J Diabetes Sci Technol 2015; 9: 687-95.

15. Mallia AK, Hermanson GJ, Krohn RI, Fujimoto EK, Smith PK. Preparation and use of a boronic acid affinity support for separation and quantitation of glycosylated haemoglobin. Anal Lett 1981; 14: 649-61.

16. Schwartz KL, Monsur JC, Bartoces MG, West PA, Neale AV. Correlation of samevisit $\mathrm{HbA1c}$ test with laboratory-based measurements: a MetroNet study. BMC Fam Pract 2005; 6: 28
17. Grant DA, Dunseath GJ, Churm R, Luzio SD. Comparison of a point-of-care analyser for the determination of HbA1c with HPLC method. Pract Lab Med 2017; 8: 26-9.

18. Arsie MP, Marchioro L, Lapolla A, Giacchetto GF, Bordin MR, Rizzotti P, et al. Evaluation of diagnostic reliability of DCA 2000 for rapid and simple monitoring of HbA1c. Acta Diabetol 2000; 37: 1-7.

19. Haliassos A, Drakopoulos I, Katritsis D, Chiotinis N, Korovesis S, Makris K. Measurement of glycated hemoglobin (HbA1c) with an automated POCT instrument in comparison with HPLC and automated immunochemistry method: Evaluation of the influence of hemoglobin variants. Clin Chem Lab Med 2006; 44: 223-7. 